Article

\title{
Promiscuous Lipase-Catalyzed Markovnikov Addition of H-Phosphites to Vinyl Esters for the Synthesis of Cytotoxic $\alpha$-Acyloxy Phosphonate Derivatives
}

\author{
Paweł Kowalczyk 1,*(D), Dominik Koszelewski ${ }^{2, *(\mathbb{D})}$, Barbara Gawdzik ${ }^{3}$, Jan Samsonowicz-Górski ${ }^{2}$ (D), \\ Karol Kramkowski ${ }^{4}$, Aleksandra Wypych ${ }^{5}$ D, Rafał Lizut ${ }^{6}$ iD and Ryszard Ostaszewski ${ }^{2}$ (D)
}

Citation: Kowalczyk, P.; Koszelewski,

D.; Gawdzik, B.; Samsonowicz-Górski,

J.; Kramkowski, K.; Wypych, A.; Lizut,

R.; Ostaszewski, R. Promiscuous

Lipase-Catalyzed Markovnikov

Addition of H-Phosphites to Vinyl

Esters for the Synthesis of Cytotoxic

$\alpha$-Acyloxy Phosphonate Derivatives.

Materials 2022, 15, 1975. https://

doi.org/10.3390/ma15051975

Academic Editor: Roman

Perez Antoñanzas

Received: 4 February 2022

Accepted: 2 March 2022

Published: 7 March 2022

Publisher's Note: MDPI stays neutral with regard to jurisdictional claims in published maps and institutional affiliations.

Copyright: (C) 2022 by the authors. Licensee MDPI, Basel, Switzerland. This article is an open access article distributed under the terms and conditions of the Creative Commons Attribution (CC BY) license (https:// creativecommons.org/licenses/by/ $4.0 /)$.
1 Department of Animal Nutrition, The Kielanowski Institute of Animal Physiology and Nutrition, Polish Academy of Sciences, Instytucka 3, 05-110 Jabłonna, Poland

2 Institute of Organic Chemistry PAS, Kasprzaka 44/52, 01-224 Warsaw, Poland; jan.samsonowicz-gorski.stud@pw.edu.pl (J.S.-G.); ryszard.ostaszewski@icho.edu.pl (R.O.)

3 Institute of Chemistry, Jan Kochanowski University, Uniwersytecka 7, 25-406 Kielce, Poland; b.gawdzik@ujk.edu.pl

4 Department of Physical Chemistry, Medical University of Bialystok, Kilińskiego 1 Str., 15-089 Białystok, Poland; kkramk@wp.pl

5 Centre for Modern Interdisciplinary Technologies, Nicolaus Copernicus University, Torun ul. Wileńska 4, 87-100 Toruń, Poland; wypych@umk.pl

6 Institute of Mathematics, Informatics and Landscape Architecture, The John Paul II Catholic University of Lublin, ul. Konstantynów 1 H, 20-708 Lublin, Poland; lizut@kul.pl

* Correspondence: p.kowalczyk@ifzz.pl (P.K.); dominik.koszelewski@icho.edu.pl (D.K.); Tel.: +48-22-765-33-01 (P.K.); +48-22-343-20-12 (D.K.)

\begin{abstract}
An enzymatic route for phosphorous-carbon- bond formation is developed by discovering new promiscuous activity of lipase. This biocatalytic transformation of phosphorous-carbon- bond addition leads to biologically and pharmacologically relevant $\alpha$-acyloxy phosphonates with methyl group in $\alpha$-position. A series of target compounds were synthesized with yields ranging from $54 \%$ to $83 \%$ by enzymatic reaction with Candida cylindracea (CcL) lipase via Markovnikov addition of $H$-phosphites to vinyl esters. We carefully analyzed the best conditions for the given reaction such as the type of enzyme, temperature, and type of solvent. The developed protocol is applicable to a range of $H$-phosphites and vinyl esters significantly simplifying the preparation of synthetically challenging $\alpha$-pivaloyloxy phosphonates. Further, the obtained compounds were validated as new potential antimicrobial drugs with characteristic E. coli bacterial strains and DNA modification recognized by the Fpg protein, $N$-methyl purine glycosylases as new substrates. The impact of the methyl group located in the $\alpha$-position of the studied $\alpha$-acyloxy phosphonates on the antimicrobial activity was demonstrated. The pivotal role of this group on inhibitory activity against selected pathogenic E. coli strains was revealed. The observed results are especially important in the case of the increasing resistance of bacteria to various drugs and antibiotics.
\end{abstract}

Keywords: $\alpha$-acyloxy phosphonates; enzymatic Markovnikov addition; lipase promiscuity Fpg protein-formamidopyrimidine; lipopolysaccharide (LPS); HIV-human immunodeficiency virus

\section{Introduction}

$\alpha$-Hydroxy phosphonates are recognized as a valuable class of substances exhibiting interesting medicinal and agricultural properties [1-4]. $\alpha$-Hydroxy phosphonate derivatives are of great importance due to their various biological actions and therapeutic applications such as bactericidal [5], fungicidal [6], antitumor [7], and HIV inhibitory activities [8]. The high interest in this class of compounds has been reflected in numerous publications on their synthesis, modification, and application not only in medical chemistry [9-14]. It was shown that further functionalization of the hydroxy group has a pivotal impact on the biological 
activity of the modified $\alpha$-hydroxy phosphonates. For example, 2-dimethylphosphonoethyl acetate which was synthesized via radical addition reaction of $H$-phosphite to vinyl acetate exhibits broad bioactivity, e.g., anti-hypoxic, soporific, anticonvulsive, and hypothermic (Figure 1) [15].<smiles>CCOP(=O)(OCC)C(O)c1cc2cc(C)ccc2n2nnnc12</smiles><smiles>C[C@@H]1O[C@@H]1P(=O)(O)O</smiles>

Fosfomycin<smiles>CCOP(=O)(OCC)C(O)c1ccccc1Oc1nc(OC)cc(OC)n1</smiles>

Herbicide<smiles>CCOP(=O)(OCC)c1cccc([N+](=O)[O-])c1</smiles>

Antioxidant<smiles>[Y][Al]NC(Cc1ccccc1)P([R])(=O)C(O)C(Cc1ccccc1)N[AlH][Y]</smiles>

HIV-protease inhibitor<smiles>CCOP(=O)(OCC)C(OC(=O)c1nnn(Cc2cccc(Cl)n2)c1C)c1ccccc1</smiles>

Cardiovascular activity Herbicidal and fungicidal activities

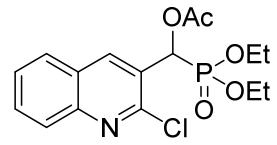

Antibacterial agent<smiles>[R]C(OC(=O)/C=C/c1ccccc1)P(=O)(OC)OC</smiles>

Herbicidal Activity (R: alkyl, aryl)<smiles>[R]C(OC(=O)c1ccccc1O)P(=O)(O)OC</smiles>

Antitumor Activity

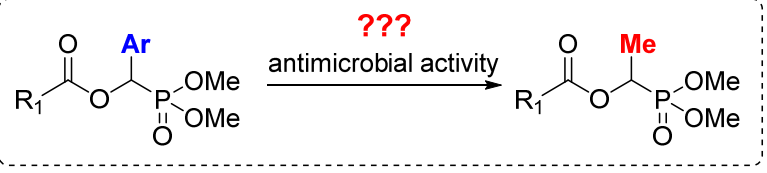

Figure 1. Biologically active $\alpha$-hydroxy phosphonate derivatives.

Due to the large number of antimicrobial resistances, there is a growing need to elaborate lead structural scaffolds that may be useful in developing potent antimicrobial drug. Furthermore, it was noticed that the antitumor activity of many chemotherapeutic compounds is directly correlated with their antibiotic features, and $\alpha$-hydroxy and $\alpha$-acyloxy phosphonate derivatives are still being rediscovered in various angles in practical clinical biochemistry and microbiological engineering. Revising toxic effect on bacterial cells of the novel organic compounds containing a phosphorus-carbon bond can provide suitable antimicrobial agents against bacterial clinical pathogens. A careful analysis of the literature data showed that there are no data related to the influence of the size of the substituent particularly methyl group in the alpha position of the $\alpha$-hydroxy phosphonate derivatives on their antimicrobial activity. Unfortunately, there are no mild and environmentally sustainable methods to synthesize these types of compounds. The available methods have disadvantages that often limit their use in the synthesis of biologically active compounds. An important aspect that must be met in the synthesis of such compounds is the lack of metal impurities, the content of which, in accordance with pharmacological requirements, cannot exceed $5 \mathrm{ppm}$. The goal of the presented studies is the development of efficient enzymatic preparation of $\alpha$-acetoxy phosphonate derivatives with methyl in the $\alpha$-position, and their validation and comparison with $\alpha$-aryl substituted derivatives as antimicrobial agents against model strains of Escherichia coli K12 (with native LPS in its structure) and R2-R4 (LPS of different lengths in its structure).

\section{Materials and Methods}

\subsection{Microorganisms and Media}

All bacterial strains were from Prof. Jolanta Łukasiewicz (Polish Academy of Sciences, Wrocław, Poland). Reagents and apparatus that were used in the work were described in detail in our earlier works in this field.

The synthesis of new compounds from the $\alpha$-hydroxy phosphonate derivatives, similarly to other compounds studied by us in previous works, may determine a new alternative to the commonly used antibiotics in clinical infections. This chemical and biological activity 
is related to two kinds of specific substituents in their structure R1 and R2 (see Scheme 1). Dysfunction of bacterial membranes containing different lengths of LPS in model bacterial strains is an ideal model to assess the effectiveness of these compounds in relation to the antibiotics used by a specific enzyme Fpg of modified bacterial DNA (Labjot, New England Biolabs, Ipswich, MA, USA).

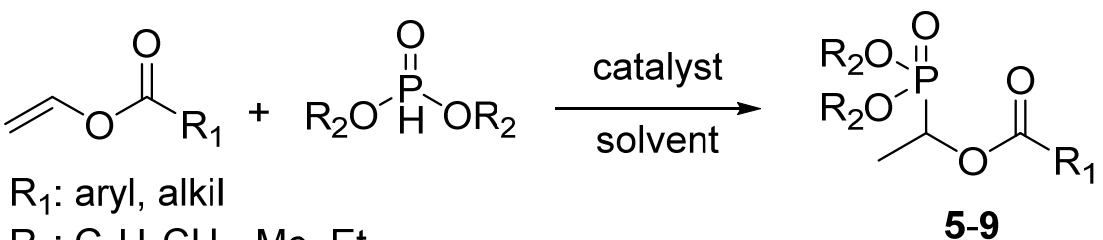

$\mathrm{R}_{2}: \mathrm{C}_{6} \mathrm{H}_{5} \mathrm{CH}_{2}$, Me, Et

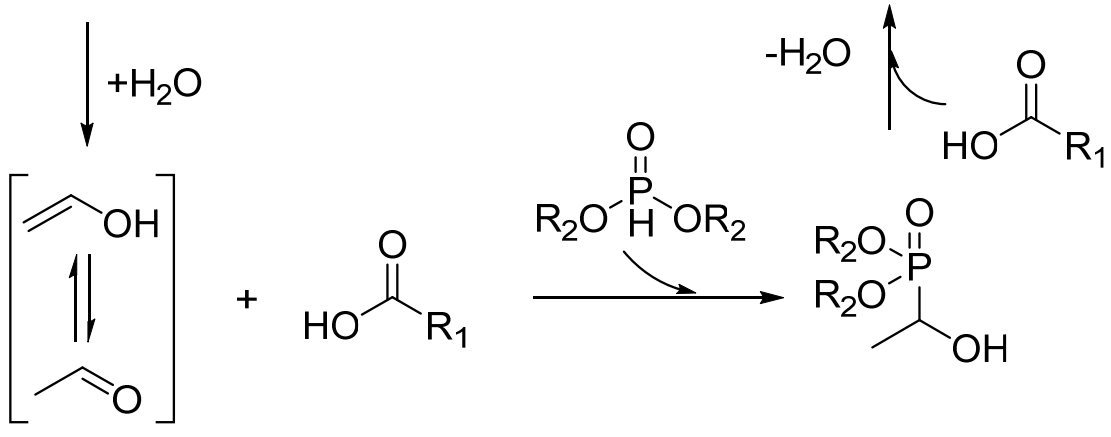

Scheme 1. Enzyme catalyzed synthesis of $\alpha$-acyloxy phosphonates 5-9.

\subsection{Statistical Analysis}

All experimental data were presented as the means \pm standard error of the mean (SEM, manufacturer, Saint Louis, MO, USA) of a minimum of three independent experiments $(\mathrm{n}=3)$. The Tukey test was used Statistical significance is indicated by $(p<0.05):{ }^{*} p<0.05$, ** $p<0.1,{ }^{* * *} p<0.01$.

\subsection{General Methods of Synthesis $\alpha$-Hydroxy Phosphonate Derivatives}

All reagents and the solvents were from Sigma-Aldrich (Saint Louis, MI, USA). NMR spectra (Saint Louis, MI, USA) were reordered on Varian apparatus (Varian, Saint Louis, MI, USA) (400 MHz), mass spectrometer was from Waters Company, Milford, USA. All specific strains such as Pseudomonas fluorescens (PfL) (catalogue number 534730, Lot. number MKBH1198V), Candida rugosa (CrL) (catalogue number 90860, Lot. number BCBH7102V), Candida cylindracea (CcL) (catalogue number 62316, Lot. number 1336707), and Bovine serum albumin were purchased from Sigma-Aldrich. Immobilized lipase from Candida antarctica B (Novozym 435) (catalogue number LC200223) was purchased from Novo Nordisk (Warsaw, Poland). Lipases from porcine pancreas, Type II (PpL) (catalogue number L-3126, Lot. number 108H1379) was purchased from Sigma-Aldrich.Dimethyl 1-hydroxy-1phenylmethylphosphonate (1) and dimethyl hydroxy-(2-nitrophenyl)methylphosphonate (3) were obtained previously [16].

Dimethyl Hydroxy-(2-nitrophenyl)methylphosphonate (2): Compound 2 was obtained according to literature procedure [16] with $69 \%$ yield $(180 \mathrm{mg}, 0.69 \mathrm{mmol})$ as a colorless solid; m.p. $166-167{ }^{\circ} \mathrm{C}$ [Lit $\left.166.5^{\circ} \mathrm{C}\right]$ [17]; ${ }^{1} \mathrm{H}$ NMR $\left(400 \mathrm{MHz}, \mathrm{CDCl}_{3}\right) \delta 8.03-7.95(\mathrm{~m}, 2 \mathrm{H})$, $7.71-7.63(\mathrm{~m}, 1 \mathrm{H}), 7.49-7.41(\mathrm{~m}, 1 \mathrm{H}), 6.27(\mathrm{dd}, J=14.0,5.9 \mathrm{~Hz}, 1 \mathrm{H}), 5.59(\mathrm{t}, J=7.0 \mathrm{~Hz}, 1 \mathrm{H})$, $3.74(\mathrm{~d}, J=2.2 \mathrm{~Hz}, 3 \mathrm{H}), 3.71(\mathrm{~d}, J=2.5 \mathrm{~Hz}, 3 \mathrm{H}) ;{ }^{31} \mathrm{P} \mathrm{NMR}\left(162 \mathrm{MHz}, \mathrm{CDCl}_{3}\right) \delta 22.22$. NMR data were in accordance with those reported in the literature [18]; LRMS (ESI) $\mathrm{m} / \mathrm{z}$ calcd for $\mathrm{C}_{9} \mathrm{H}_{13} \mathrm{NO}_{6} \mathrm{P}[\mathrm{M}+\mathrm{H}]^{+} 262.1$, found 262.1.

Dibenzyl (1-Hydroxy-2-phenylpropyl)phosphonate (4). Compound 4 was obtained as a mixture of diastereoisomers at 2:1 ratio according to literature procedure [16] with $53 \%$ yield $(210 \mathrm{mg}, 0.53 \mathrm{mmol})$ as a colorless semi-solid; ${ }^{1} \mathrm{H} \mathrm{NMR}\left(400 \mathrm{MHz}, \mathrm{CDCl}_{3}\right) \delta$ 7.43-7.15 (m, 23H), 5.05-4.86 (m, 5H), $4.80(\mathrm{dd}, J=11.8,8.9 \mathrm{~Hz}, 1 \mathrm{H}), 4.10(\mathrm{td}, J=6.2,1.0 \mathrm{~Hz}$, 
1H), (diastereoisomers) 3.33-3.19 (m, 2H), $1.45(\mathrm{~d}, \mathrm{~J}=7.1 \mathrm{~Hz}, 3 \mathrm{H})$, (diastereoisomer) 1.40 $(\mathrm{d}, J=7.2 \mathrm{~Hz}, 1 \mathrm{H}) ;{ }^{31} \mathrm{P} \mathrm{NMR}\left(162 \mathrm{MHz}, \mathrm{CDCl}_{3}\right) \delta 24.99,24.72$. HRMS (EI) $\mathrm{m} / \mathrm{z}$ calcd for $\mathrm{C}_{23} \mathrm{H}_{26} \mathrm{O}_{4} \mathrm{P}[\mathrm{M}+\mathrm{H}]^{+}$397.1569, found 397.1549.

General Procedure for the Synthesis of $\alpha$-Hydroxy Phosphonate Derivatives 5-9 and Phosphonate 10

General procedure for enzyme catalyzed addition reaction of $H$-phosphites to vinyl esters. A mixture of the corresponding vinyl ester or dimethyl maleate $(1 \mathrm{mmol})$, Candida cylindracea lipase $(\mathrm{CcL}, 80 \mathrm{mg})$ and the corresponding $H$-phosphite $(1 \mathrm{mmol})$ in $n$-hexane $(2 \mathrm{~mL})$ was shaken at $200 \mathrm{rpm}$ at $40{ }^{\circ} \mathrm{C}$ for $18 \mathrm{~h}$. After the completion of reaction. the catalyst was separated on a glass frit funnel. The residue was washed with ethyl acetate. The combined organic phase was concentrated under vacuum. The resulting residue was purified by column chromatography (silica gel, eluent: ethyl acetate/hexanes, 6:4) to afford the target $\alpha$-hydroxy phosphonate derivatives 5-9 and phosphonate 10. The yields of the derivatives are shown in Figure 2. The structures of all compounds were confirmed using NMR and mass spectroscopy.<smiles>CCOP(=O)(OCC)C(C)OC(=O)c1ccccc1</smiles>

$6(77 \%)$<smiles>COP(=O)(OC)C(O)c1ccccc1[N+](=O)[O-]</smiles>

$2(69 \%)$<smiles>CCC(=O)OC(C)P(=O)(OBr)OCc1ccccc1</smiles><smiles>CC(OC(=O)C(C)(C)C)P(=O)(O)OCc1ccccc1</smiles>

$8(54 \%)$<smiles>CC(c1ccccc1)C(O)P(=O)(OBr)OCc1ccccc1</smiles><smiles>COP(=O)(OC)C(C)OC(=O)/C=C/c1ccccc1</smiles>
$5(61 \%)$<smiles>COC(=O)CC(C(=O)OC)P(=O)(O)OBr</smiles>

Figure 2. Phosphonates obtained via enzyme catalyzed Pudovik reaction and Markovnikov addition. Yields in brackets provided for isolated products $\mathbf{2 , 4}$ and $\mathbf{5 - 1 0 .}$

1-(Dimethoxyphosphoryl)ethyl cinnamate (5). Compound 5 was obtained according to the general procedure as colorless oil with $61 \%$ yield $(173 \mathrm{mg}, 0.61 \mathrm{mmol}) ;{ }^{1} \mathrm{H} \mathrm{NMR}(400 \mathrm{MHz}$, $\left.\mathrm{CDCl}_{3}\right) \delta 7.74(\mathrm{~d}, J=16.0 \mathrm{~Hz}, 1 \mathrm{H}), 7.57-7.48(\mathrm{~m}, 2 \mathrm{H}), 7.44-7.32(\mathrm{~m}, 3 \mathrm{H}), 6.47(\mathrm{~d}, J=16.0 \mathrm{~Hz}$, $1 \mathrm{H}), 5.45(\mathrm{dq}, J=8.5,7.1 \mathrm{~Hz}, 1 \mathrm{H}), 3.82(\mathrm{dd}, J=10.6,6.7 \mathrm{~Hz}, 6 \mathrm{H}), 1.55(\mathrm{dd}, J=16.8,7.1 \mathrm{~Hz}, 3 \mathrm{H})$; ${ }^{31} \mathrm{P} \mathrm{NMR}\left(162 \mathrm{MHz}, \mathrm{CDCl}_{3}\right) \delta 24.11$. NMR data were in accordance with those reported in the literature [19]. LRMS (ESI) $\mathrm{m} / \mathrm{z}$ calcd for $\mathrm{C}_{13} \mathrm{H}_{17} \mathrm{O}_{5} \mathrm{P}[\mathrm{M}+\mathrm{H}]^{+} 285.1$, found 285.1.

1-Benzoyloxy-1-diethylphosphonylethane (6). Compound 6 was obtained according to the general procedure as colorless oil with $77 \%$ yield $(210 \mathrm{mg}, 0.77 \mathrm{mmol}) ;{ }^{1} \mathrm{H} \mathrm{NMR}(400 \mathrm{MHz}$, $\left.\mathrm{CDCl}_{3}\right) \delta 8.13-7.99(\mathrm{~m}, 2 \mathrm{H}), 7.63-7.52(\mathrm{~m}, 1 \mathrm{H}), 7.52-7.38(\mathrm{~m}, 2 \mathrm{H}), 5.52(\mathrm{dq}, J=8.6,7.1 \mathrm{~Hz}$, $1 \mathrm{H}), 4.28-4.11(\mathrm{~m}, 4 \mathrm{H}), 1.58(\mathrm{dd}, J=16.7,7.1 \mathrm{~Hz}, 3 \mathrm{H}), 1.32(\mathrm{td}, J=7.1,1.5 \mathrm{~Hz}, 6 \mathrm{H}) ;{ }^{13} \mathrm{C}$ NMR $\left(100 \mathrm{MHz}_{\mathrm{CDCl}}\right) \mathrm{CDC}_{3}$ 165.3, 133.3, 129.8, 129.5, 128.4, 65.8, 64.1, 62.9, 62.8, 62.7, 62.6, 16.5, $16.4,16.3,15.2 ;{ }^{31} \mathrm{P}$ NMR (162 MHz, $\left.\mathrm{CDCl}_{3}\right) \delta$ 21.38. HRMS (EI) m/z calcd for $\mathrm{C}_{13} \mathrm{H}_{19} \mathrm{O}_{5} \mathrm{P}$ $[\mathrm{M}+\mathrm{H}]^{+}$286.0970, found 286.0977 .

Dibenzyl(1-propionoxy ethyl)phosphonat (7). Compound 7 was obtained according to the general procedure as colorless oil with $83 \%$ yield $(301 \mathrm{mg}, 0.83 \mathrm{mmol}) ;{ }^{1} \mathrm{H} \mathrm{NMR}(400 \mathrm{MHz}$, $\left.\mathrm{CDCl}_{3}\right) \delta 7.38-7.16(\mathrm{~m}, 10 \mathrm{H}), 5.31(\mathrm{dq}, J=8.5,7.1 \mathrm{~Hz}, 1 \mathrm{H}), 5.17-4.92(\mathrm{~m}, 4 \mathrm{H}), 2.36-2.18$ $(\mathrm{m}, 2 \mathrm{H}), 1.44(\mathrm{dd}, J=17.1,7.1 \mathrm{~Hz}, 3 \mathrm{H}), 1.07(\mathrm{t}, J=7.5 \mathrm{~Hz}, 3 \mathrm{H}) ;{ }^{13} \mathrm{C} \mathrm{NMR}\left(100 \mathrm{MHz}, \mathrm{CDCl}_{3}\right)$ $\delta 173.1,135.9,128.6,128.5,128.5,128.4,127.9,127.8,68.1,68.0,68.0,67.9,65.2,63.5,27.3$, $15.0,8.9 ;{ }^{31} \mathrm{P}$ NMR $\left(162 \mathrm{MHz}, \mathrm{CDCl}_{3}\right) \delta 22.68$. HRMS (EI) $\mathrm{m} / \mathrm{z}$ calcd for $\mathrm{C}_{19} \mathrm{H}_{24} \mathrm{O}_{5} \mathrm{P}[\mathrm{M}+$ $\mathrm{H}]^{+}$363.1361, found 363.1361.

2,2-Dimethylpropanyloxy1-dibenzylphosphonylethane (8). Compound 8 was obtained according to the general procedure as colorless oil with $54 \%$ yield $(211 \mathrm{mg}, 0.54 \mathrm{mmol})$; ${ }^{1} \mathrm{H}$ NMR $\left(400 \mathrm{MHz}, \mathrm{CDCl}_{3}\right) \delta 7.36-7.30(\mathrm{~m}, 10 \mathrm{H}), 5.32(\mathrm{dq}, J=8.2,7.1 \mathrm{~Hz}, 1 \mathrm{H}), 5.05(\mathrm{ddd}$, 
$J=12.1,8.0,1.4 \mathrm{~Hz}, 4 \mathrm{H}), 1.43(\mathrm{dd}, J=17.1,7.0 \mathrm{~Hz}, 3 \mathrm{H}), 1.15(\mathrm{~s}, 9 \mathrm{H}) ;{ }^{13} \mathrm{C}$ NMR $(100$ $\left.\mathrm{MHz}, \mathrm{CDCl}_{3}\right) \delta 177.0,136.0,128.5,127.9,127.7,126.9,68.0,67.9,63.3,38.7,26.9,14.9 ;{ }^{31} \mathrm{P}$ NMR $\left(162 \mathrm{MHz}, \mathrm{CDCl}_{3}\right) \delta$ 22.67. HRMS (EI) $\mathrm{m} / \mathrm{z}$ calcd for $\mathrm{C}_{21} \mathrm{H}_{28} \mathrm{O}_{5} \mathrm{P}[\mathrm{M}+\mathrm{H}]^{+} 391.1674$, found 391.1669 .

1-(Dibenzylphosphoryl)ethyl dodecanoate (9). Compound 9 was obtained according to the general procedure as colorless oil with $81 \%$ yield $(396 \mathrm{mg}, 0.81 \mathrm{mmol}) ;{ }^{1} \mathrm{H}$ NMR (400 $\left.\mathrm{MHz}, \mathrm{CDCl}_{3}\right) \delta 7.41-7.27(\mathrm{~m}, 10 \mathrm{H}), 5.32(\mathrm{dq}, J=8.7,7.1 \mathrm{~Hz}, 1 \mathrm{H}), 5.16-4.98(\mathrm{~m}, 4 \mathrm{H}), 2.33-2.16$ $(\mathrm{m}, 2 \mathrm{H}), 1.55(\mathrm{t}, J=7.2 \mathrm{~Hz}, 2 \mathrm{H}), 1.44(\mathrm{dd}, J=17.1,7.1 \mathrm{~Hz}, 3 \mathrm{H}), 1.35-1.20(\mathrm{~m}, 17 \mathrm{H}), 0.88(\mathrm{t}$, $J=6.8 \mathrm{~Hz}, 3 \mathrm{H} ;{ }^{13} \mathrm{C} \mathrm{NMR}\left(100 \mathrm{MHz}, \mathrm{CDCl}_{3}\right) \delta 172.4,136.1,128.5,128.5,128.4,128.4,127.9$, $127.9,127.9,127.8,68.0,68.0,67.9,65.1,63.4,34.0,31.8,30.8,29.5,29.4,29.3,29.2,29.1$, 29.0, 24.8, 22.6, 15.0, 14.0; ${ }^{31} \mathrm{P}$ NMR $\left(162 \mathrm{MHz}, \mathrm{CDCl}_{3}\right) \delta 22.72$. HRMS (EI) $\mathrm{m} / \mathrm{z}$ calcd for $\mathrm{C}_{28} \mathrm{H}_{42} \mathrm{O}_{5} \mathrm{P}[\mathrm{M}+\mathrm{H}]^{+}$489.2770, found 489.2764.

Dimethyl 2-(dibenzyloxyphosphoryl)succinate (10). Compound $\mathbf{1 0}$ was obtained according to the general procedure as colorless oil with $68 \%$ yield $(276 \mathrm{mg}, 0.68 \mathrm{mmol}) ;{ }^{1} \mathrm{H}$ NMR $\left(400 \mathrm{MHz}, \mathrm{CDCl}_{3}\right) \delta 7.45-7.29(\mathrm{~m}, 10 \mathrm{H}), 5.14-4.95(\mathrm{~m}, 4 \mathrm{H}), 3.70(\mathrm{~d}, J=0.7 \mathrm{~Hz}, 3 \mathrm{H}), 3.64$ $(\mathrm{s}, 3 \mathrm{H}), 3.53(\mathrm{ddd}, J=24.3,11.1,3.7 \mathrm{~Hz}, 1 \mathrm{H}), 3.06(\mathrm{ddd}, J=17.5,11.1,8.1 \mathrm{~Hz}, 1 \mathrm{H}), 2.79(\mathrm{ddd}$, $J=17.5,9.8,3.7 \mathrm{~Hz}, 1 \mathrm{H}) ;{ }^{13} \mathrm{C}$ NMR $\left(100 \mathrm{MHz}, \mathrm{CDCl}_{3}\right) \delta 171.2,168.4,135.7,128.6,128.6$, $128.5,127.9,68.4,68.4,68.3,52.8,52.1,42.0,40.7,31.1,31.1 ;{ }^{31} \mathrm{P}$ NMR $\left(162 \mathrm{MHz}, \mathrm{CDCl}_{3}\right)$ $\delta$ 22.05. HRMS (EI) $\mathrm{m} / \mathrm{z}$ calcd for $\mathrm{C}_{20} \mathrm{H}_{24} \mathrm{O}_{7} \mathrm{P}[\mathrm{M}+\mathrm{H}]^{+} 407.1260$, found 407.1263.

\section{Results}

\subsection{Chemistry}

Organophosphorus compounds display a broad spectrum of various important biological activities [20]. Among others, $\alpha$-hydroxy phosphonates have grasped attention towing to their wide range bioactivity. $\alpha$-hydroxy phosphonates are usually synthesized by the base-catalyzed Pudovik reaction, the addition of dialkyl phosphite to an oxo compound $[4,21]$. Recently, we have shown that this reaction can be catalyzed by lipases providing desired products with high yield under environmentally sustainable conditions [16]. $\alpha$-acyloxy phosphonates, an acyl derivative of $\alpha$-hydroxy phosphonates known to exhibit potential bioactivity as herbicides [19,22-24], anticancer agents [25], fungicides [26], and insecticides [20]. Several articles described the acylation of $\alpha$-hydroxy phosphonates with carboxylic acid chlorides using either triethylamine or pyridine [27,28]. Moreover, acetic anhydride has been used with copper(II) trifluoromethanesulfonate or trichlorotitanium(IV) trifluoromethanesulfonate as a catalyst [29,30]. Carboxylic acids can be also used as an acylating agents for $\alpha$-hydroxy phosphonates supported by coupling reagents e.g., $N, N^{\prime}$-dicyclohexylcarbodiimide and 4-dimethylaminopyridineas as the base [31]. Apart from Michaelis-Arbuzov and Michaelis-Becker reactions, the phosphorus-carbon bond is formed using phospha-Michael addition under basic conditions [32-37]. Therefore, the possibility of using this approach in the synthesis of bioactive $\alpha$-acyloxy phosphonates should be considered. Although some chemical strategies based on addition of $H$-phosphites towards the synthesis of $\alpha$-acyloxy phosphonates catalyzed either by sodium ethanolate or $\mathrm{K}_{2} \mathrm{CO}_{3} / 18$-crown- 6 ether have been reported $[38,39]$, the biocatalytic synthesis of target $\alpha$-acyloxy phosphonates via addition of $H$-phosphites to unsaturated carbon-carbon bond remains unexploited.

The use of hydrolases as catalysts in various variants of Michael addition of different nucleophilic partners was widely discussed in the literature [40-44]. Recently, it was also shown that lipases catalyze selectively Markovnikov additions of thiols and amines to vinyl esters in different organic solvents [45-48]. Consequently, recognition of the new promiscuous activities of hydrolases provides novel processes to access pharmaceutically effective compounds [49].

As a continuation of our research on sustainable protocols, [50-53] we paid attention to find an environmentally friendly method for desired $\alpha$-hydroxy phosphonates 1-4 [16] and $\alpha$-acyloxy phosphonates 5-10 (Figure 2). 
Based on literature data regarding enzymes known-bioactivity [54], the model addition reaction of dimethyl phosphite $(1 \mathrm{mmol})$ and vinyl cinnamate $(1 \mathrm{mmol})$ was conducted in $n$-hexane at $40{ }^{\circ} \mathrm{C}$ (Scheme 1) (Table 1, entry 1). A series of commercially available lipases and one domestically prepared pig liver acetone powder were screened as catalysts. The results are summarized in Table 1.

Table 1. Model addition reaction catalyzed by enzymes. ${ }^{a}$ Optimization studies.

\begin{tabular}{ccccc}
\hline Entry & Catalyst & T ( ${ }^{\circ}$ C) & Solvent & Yield [\%] $^{\text {e }}$ \\
\hline 1 & None & 40 & $n$-hexane & $<1$ \\
2 & Candida cylindracea lipase (CcL) & 40 & $n$-hexane & 61 \\
3 & Candida cylindracea lipase (CcL) & 40 & TBME & 42 \\
4 & Candida cylindracea lipase (CcL) & 40 & DMSO & 12 \\
5 & Candida cylindracea lipase (CcL) & 40 & THF & 37 \\
6 & Candida cylindracea lipase (CcL) & 40 & toluene & 22 \\
7 & Candida cylindracea lipase (CcL) & 40 & $n$-hexane & 59 \\
8 & Candida cylindracea lipase (CcL) & 30 & $n$-hexane & 49 \\
9 & Candida cylindracea lipase (CcL) & 50 & $n$-hexane & 54 \\
10 & Pseudomonas fluorescens lipase (PfL) & 40 & $n$-hexane & 13 \\
11 & Porcine pancreas lipase (PPL) & 40 & $n$-hexane & 25 \\
12 & Candida rugosa lipase (CrL) & 40 & $n$-hexane & 39 \\
13 & Novine serum albumin (BSA) & 40 & $n$-hexane & 9 \\
14 & Pig liver acetone powder (PLAP) & 40 & $n$-hexane & 6 \\
15 & Denatured PPL d & 40 & $n$-hexane & $<5$
\end{tabular}

a Reaction conditions: vinyl cinnamate (1 mmol), dimethyl phosphite (1 mmol), and enzyme (80 mg) in solvent $(2 \mathrm{~mL})$ for $18 \mathrm{~h}, 200 \mathrm{rpm} .{ }^{\mathrm{b}} \mathrm{CcL}(100 \mathrm{mg}) .{ }^{\mathrm{c}}$ Domestically prepared. ${ }^{\mathrm{d}}$ Thermally deactivated at $100{ }^{\circ} \mathrm{C}$ for $24 \mathrm{~h}$. e Isolated yield of 5 after purification.

From above enzymatic screening, $\mathrm{CcL}$ was found as the best catalyst among the lipases checked for this addition reaction (Table 1, entry 2). The progress of the formation of target product 5 was monitored by TLC (thin layer chromatography). In less than 10 hours, the $\alpha$-acyloxy phosphonate 5 was obtained in good yield (57\%), and no significant increase in reaction yield was noticed after 18 hour (61\%). In the blank reaction, without enzyme, no reaction proceeded (Table 1 , entry 1 ). To confirm the promiscuous activity of CcL in Markovnikov addition, non-catalytic bovine serum albumin (BSA) [55] and thermally deactivated CCL were used. The results indicated that BSA and denatured CcL gave only traces of product 5 (Table 1, entries 14 and 16). These results clearly show that the peculiar active site of $\mathrm{CcL}$ is responsible for the studied addition reaction of $H$-phosphite to vinyl ester.

Considering the impact of solvent on enzyme stability it can change reactivity of enzyme [56]. To find the efficient medium, we conducted the model reaction in various solvents; tert-butyl methyl ether (TBME), dimethyl sulfoxide (DMSO), tetrahydrofuran (THF), dichloroethane (DCM), and toluene. The obtained results revealed that the solvent have significant effects on CCL activity. As shown in Table 1, the lipase from Candida cylindracea was active in all tested solvents, and the non-protic solvents such as $n$-hexane and TBME were found to be more suitable. Therefore, $n$-hexane was applied in the following process. Obtained results remain in agreement with the literature data for enzymatic azaMichael addition [54]. In the next step, the impact of enzyme quantity was investigated. A slight increase in yield of target compound 5 was noticed by raising the amount of $\mathrm{CcL}$ from $80 \mathrm{mg}$ to $100 \mathrm{mg}$. Thus, the further reactions were conducted with $80 \mathrm{mg}$ of CcL. Enzyme activity and stability are strongly associated with the temperature of reactions [52]. To verify the effect of temperature, we conducted model reaction in temperature from $30{ }^{\circ} \mathrm{C}$ to $50{ }^{\circ} \mathrm{C}$; however, the yield was reduced above $40{ }^{\circ} \mathrm{C}$, which may be due to changes in the quaternary structure of the used enzyme (Table 1, entries 8 and 9). It is noteworthy to mention that the studied addition reaction catalyzed by $\mathrm{CcL}$ afforded no by-products resulting from anti-Markovnikov addition or hydrolysis. Unfortunately, obtained chiral 
product exhibited low or no optical activity what remains in agreement with literature data regarding lipase catalyzed Michael-type additions [43] or Markovnikov addition of thiols and amines to vinyl esters [45-48]. Due to the fact that the target $\alpha$-acyloxy phosphonates (Figure 2) under studied conditions can be formed in two different ways: by the direct addition of $H$-phosphite to the double bond or by the enzymatic cascade reaction involving $\alpha$-hydroxy phosphonate synthesis [16] from acetaldehyde derived from vinyl ester hydrolysis via enzyme catalyzed Pudovik reaction and further esterification with carboxylic acid. Additional experiments under reaction course were performed. Under the developed conditions, neither the formation of the $\alpha$-hydroxy phosphonate nor enzymatic esterification was noticed. The obtained results allow to state that we are dealing with a direct $H$-phosphite addition reaction to vinyl ester.

The reusability of an enzyme is an important feature that significantly increases the attractiveness of the developed method by significantly reducing overall costs. In this work, Candida cylindracea lipase was reused up to four times with gradual decrease of the yield to $39 \%$ after four cycles.

Finally, we explored the developed reaction conditions to various vinyl esters and $H$-phosphites which resulted in $\alpha$-acyloxy phosphonate derivatives 5-9 with moderate to high yields (Figure 2). Developed protocol provides straightforward and direct access to $\alpha$-acyloxy phosphonates 5 and $\mathbf{6}$, which are structural analogs of compounds with documented herbicidal and antitumor activities (Figure 1). The Markovnikov addition to sterically hindered vinyl pivalate provided product 8 with lower yield (54\%, Figure 2$)$. The addition of $H$-phosphonates to vinyl benzoate and vinyl cinnamate provided products with slightly lower yields than with aliphatic vinyl esters. It can be because of weak nucleophilic character of aromatic acid vinyl esters compared to aliphatic ones. To our delight, the developed conditions of the enzymatic addition reaction allowed for the phospha-Michael addition of $H$-phosphonate to dimethyl maleate, what resulted in phosphonate 10 with $68 \%$ yield (Figure 2). This opens up new possibilities for the use of lipase promiscuity in the formation of phosphorus-carbon bonds. The structures of compounds 2, $\mathbf{4}$ and 5-10 are presented in experimental part (Supplementary Materials Figures S4-S24).

\subsection{Cytotoxic Studies of the Library of $\alpha$-Hydroxy Phosphonate Derivatives}

The obtained results show that all tested $\alpha$-hydroxy phosphonate derivatives have a cytotoxic effect in all analyzed $E$. coli bacterial strains differing in LPS length. Different inhibitory activity was noted depending on the nature of the substituent in the $\alpha$-position of the tested compounds. All tested $\alpha$-acyloxy phosphonates 5-7 with methyl group at $\alpha$-position exhibited higher activity against strains R2, R3, and R4 than commonly used antibiotics (Figures 3-7). The MIC and MBC test values for each model of E. coli R2-R4 and K12 strains were visible in all analyzed growth microplates after the addition of resazurin. 


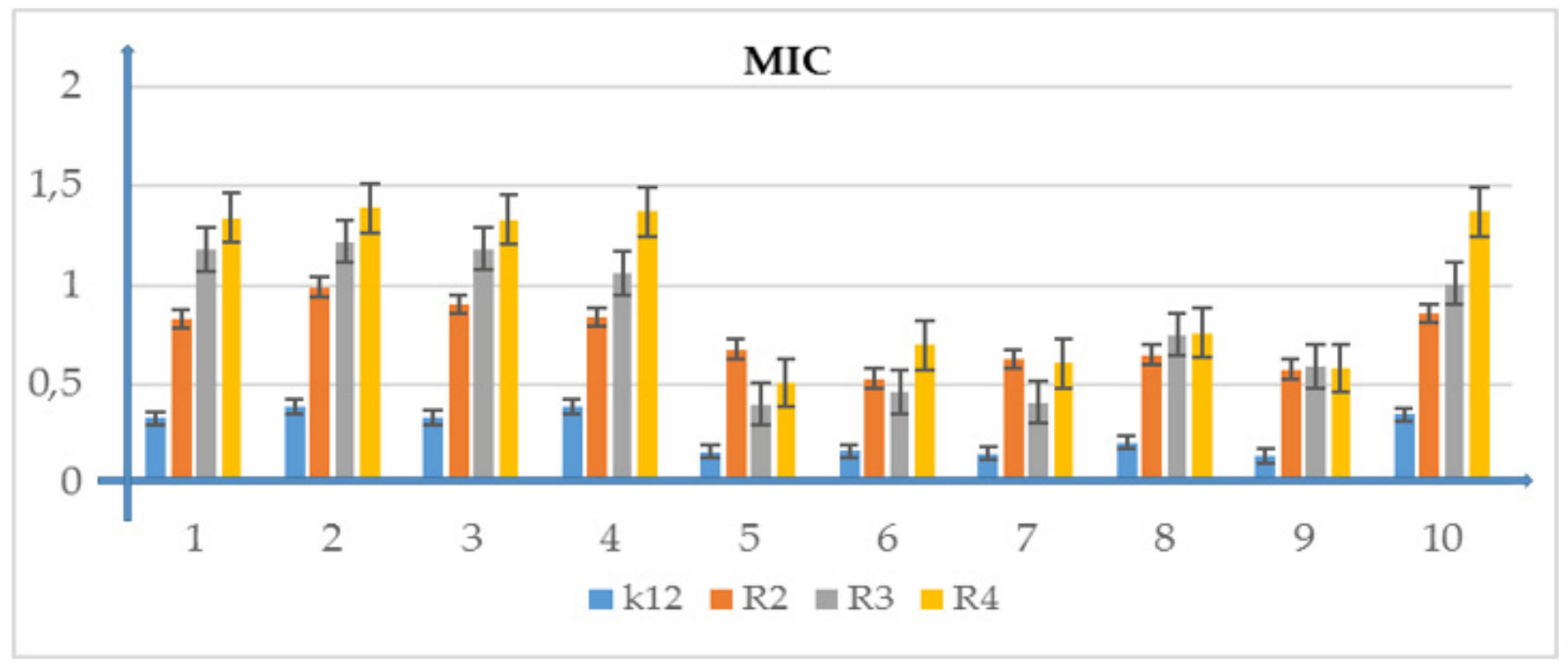

Figure 3. Minimum inhibitory concentration (MIC) of the phosphonate derivatives in model bacterial strains. The $x$-axis features compounds $\mathbf{1 - 1 0}$ used sequentially. The $y$-axis shows the MIC value in $\mu \mathrm{g} / \mathrm{mL}^{-1}$. Investigated strains of E. coli $\mathrm{K} 12$ as control (blue), R2 strains (orange), R3 strain (grey), and $\mathrm{R} 4$ strain (yellow). The $y$-axis shows the $\mathrm{MBC}$ value in $\mu \mathrm{g} / \mathrm{mL}^{-1}$. The order in which the compounds were applied to the plate is shown in Supplementary Materials Figure S1.

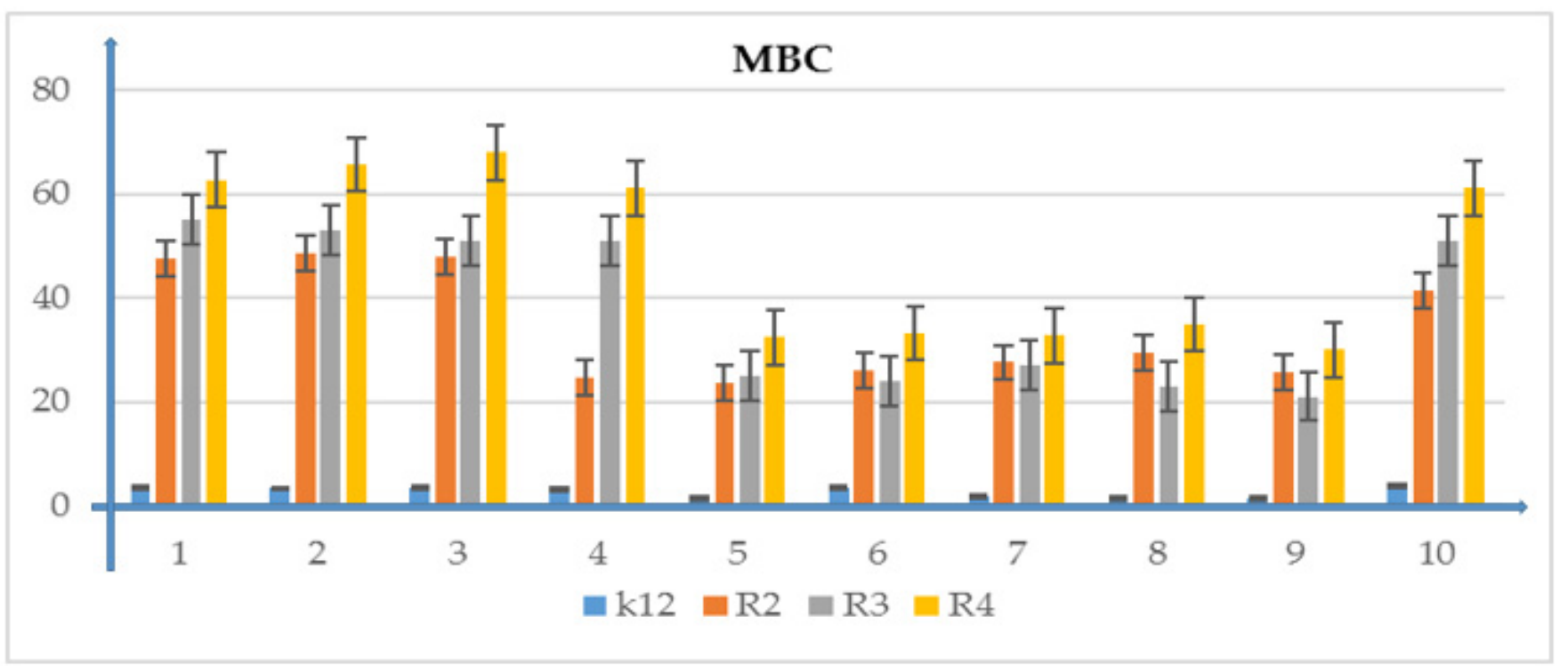

Figure 4. Minimum bactericidal concentration (MBC) of the phosphonate derivatives. The $x$-axis features compounds 1-10 used sequentially. The $y$-axis shows the MIC value in $\mu \mathrm{g} / \mathrm{mL}^{-1}$. Investigated strains of E. coli $\mathrm{K} 12$ as control (blue), R2 strains (orange), R3 strain (grey), and R4 strain (yellow). The $y$-axis shows the MBC value in $\mu \mathrm{g} / \mathrm{mL}^{-1}$. The order in which the compounds were applied to the plate is shown in Supplementary Materials Figure S1. 


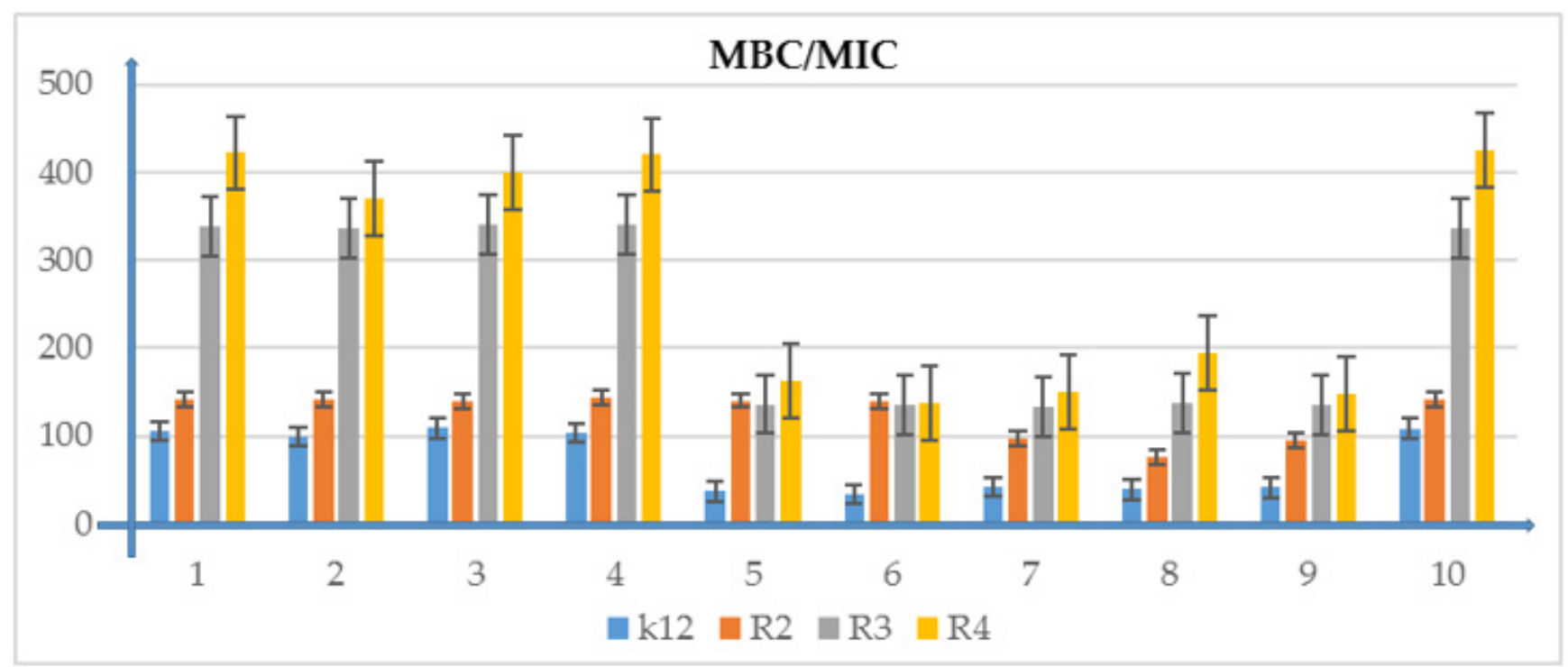

Figure 5. The ratio of MBC/MIC of the phosphonate derivatives. The $x$-axis features compounds 1-10 used sequentially. The $y$-axis shows the MIC value in $\mu \mathrm{g} / \mathrm{mL}^{-1}$. Investigated strains of $E$. coli $\mathrm{K} 12$ as control (blue), R2 strains (orange), R3 strain (grey), and R4 strain (yellow). The $y$-axis shows the $\mathrm{MBC}$ value in $\mu \mathrm{g} / \mathrm{mL}^{-1}$. The order in which the compounds were applied to the plate is shown in Supplementary Materials Figure S1.

Table 2. Statistical analysis of all analyzed compounds by MIC, MBC, and MBC/MIC; $<0.05$ *, $<0.01^{* *},<0.001^{* * *}$.

\begin{tabular}{cccccccccc}
\hline No. of Samples & $\mathbf{1}$ & $\mathbf{2}$ & $\mathbf{3}$ & $\mathbf{4}$ & $\mathbf{5}$ & $\mathbf{6 , 7}$ & $\mathbf{8 , 9}$ & $\mathbf{1 0}$ & Type of Test \\
\hline K12 & $* * *$ & $* * *$ & $* * *$ & $* * *$ & $*$ & $*$ & $*$ & $* * *$ & MIC \\
R2 & $* * *$ & $* * *$ & $* * *$ & $* * *$ & $*$ & $*$ & $*$ & $* * *$ & MIC \\
R3 & $* * *$ & $* * *$ & $* * *$ & $* * *$ & $*$ & $*$ & $*$ & $* * *$ & MIC \\
R4 & $* * *$ & $* * *$ & $* * *$ & $* * *$ & $*$ & $*$ & $*$ & $* * *$ & MIC \\
K12 & $*$ & $*$ & $* *$ & $*$ & $* *$ & $*$ & $*$ & $* *$ & MBC \\
R2 & $* *$ & $*$ & $* *$ & $*$ & $* *$ & $*$ & $*$ & $* *$ & MBC \\
R3 & $* *$ & $*$ & $* *$ & $*$ & $* *$ & $*$ & $*$ & $* *$ & MBC \\
R4 & $* *$ & $*$ & $* *$ & $*$ & $* *$ & $*$ & $*$ & $* *$ & MBC \\
K12 & $* * *$ & $*$ & $*$ & $*$ & $*$ & $*$ & $*$ & $* * *$ & MBC/MIC \\
R2 & $* * *$ & $*$ & $*$ & $*$ & $*$ & $*$ & $* *$ & $* * *$ & MBC/MIC \\
R3 & $* * *$ & $*$ & $*$ & $*$ & $*$ & $*$ & $* *$ & $* * *$ & MBC/MIC \\
R4 & $* * *$ & $*$ & $*$ & $*$ & $*$ & $*$ & $* *$ & $* * *$ & MBC/MIC \\
\hline
\end{tabular}

Model strains of E.coli were plotted in all 48-well plates observed: K12, R2-R4 which were treated with the analyzed compounds. From analysis of the MIC and MBC assays, color changes were observed for all compounds tested but at different levels and at different dilutions. Bacterial strains R3 and R4 were the most susceptible to modification with these compounds due to the increasing length of their LPS (visible dilutions of $10^{-2}$ corresponding to a concentration of $0.0015 \mu \mathrm{M}$ ) than strains K12 and R2 (visible dilutions of $10^{-6}$ corresponding to a concentration of $0.02 \mu \mathrm{M}$ ). The analyzed $\mathrm{R} 4$ strain was the most sensitive of all strains, probably due to the longest length of the lipopolysaccharide chain in the bacterial membrane. In all analyzed cases, the MBC values were approximately 50 times higher than the MIC values (Figures 3-7 and Table 2). 


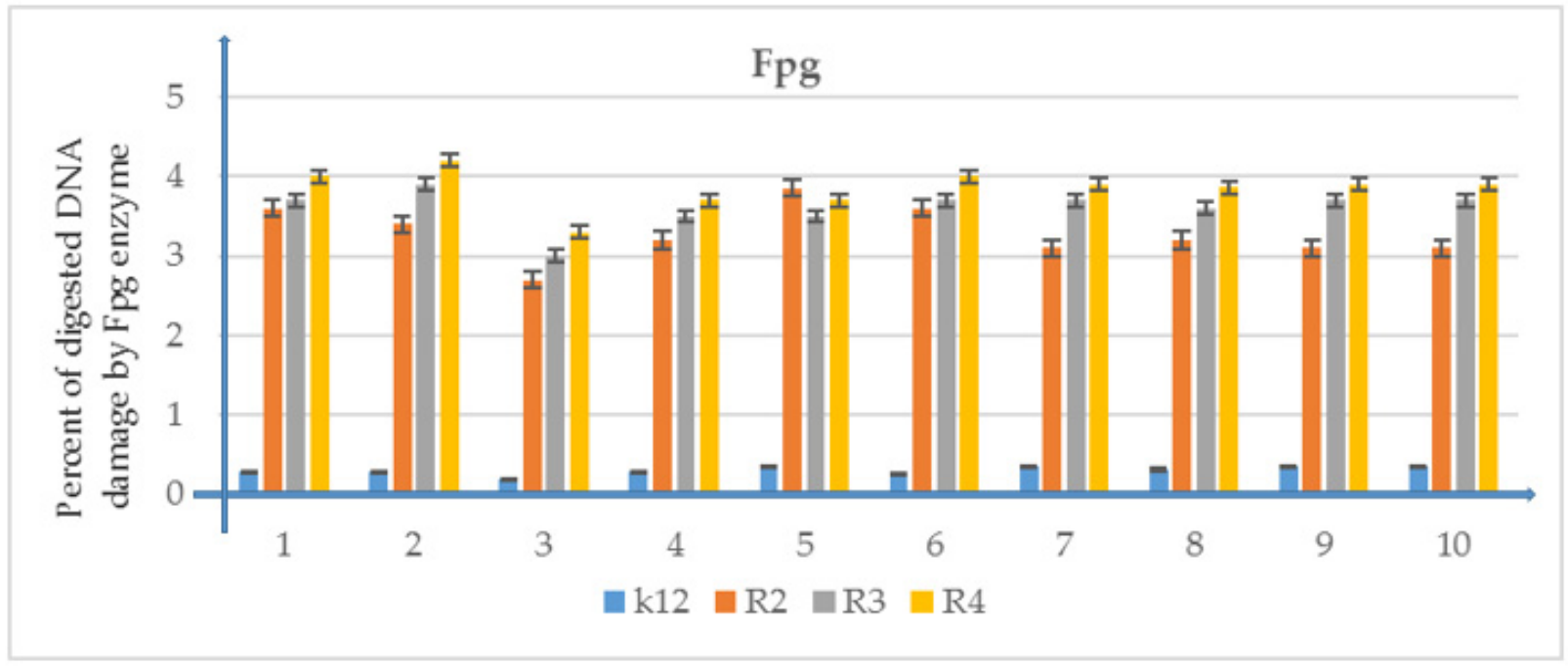

Figure 6. Percentage of plasmid DNA recognized by Fpg enzyme ( $y$-axis) with model bacterial, K12, and R2-R4 strains ( $x$-axis). All analyzed compounds numbered were statistically significant at $<0.05$ (see Table 2 and Supplementary Materials Figure S2 panel A and B).

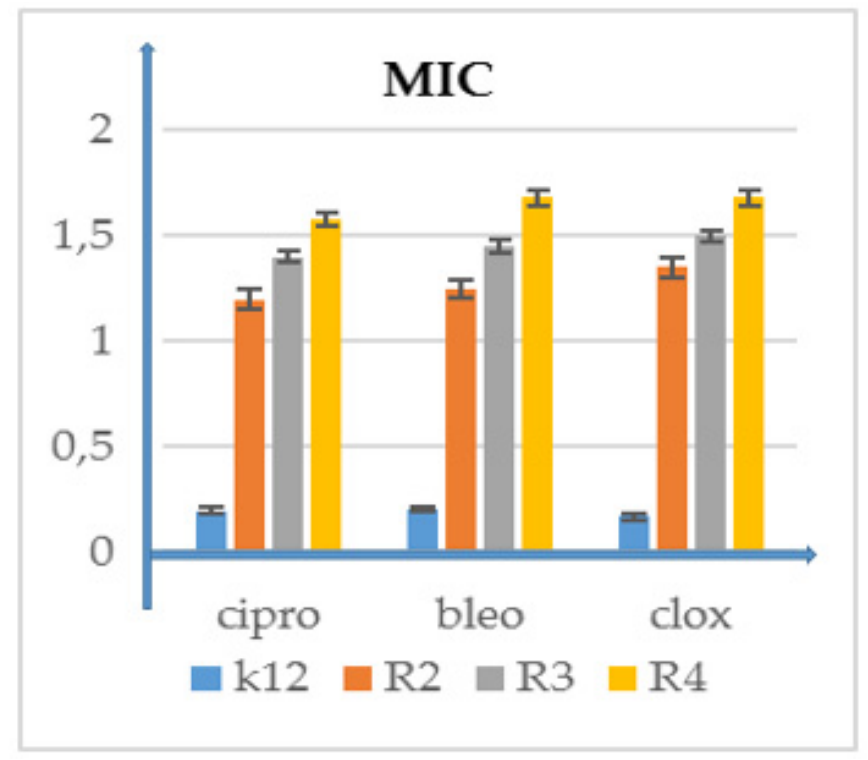

Figure 7. Examples of MIC with model bacterial strains K12, R2, R3, and R4 for studying antibiotics ciprofloxacin (cipro), bleomycin (bleo), and cloxacillin (clox). The $x$-axis features antibiotics used sequentially. The $y$-axis features the MIC value in $\mu \mathrm{g} / \mathrm{mL}^{-1}$. Supplementary Materials Figure S1.

3.3. Analysis of Bacterial DNA Isolated from E. coli R2-R4 Strains Modified with $\alpha$-Hydroxy Phosphonate Derivatives

The analyzed compounds were selected for further analyzes by modifying them with the bacterial DNA obtained from the analyzed strains. Modified bacterial DNA was digested by using Fpg protein. We wanted to observe whether the resulting modifications in bacterial DNA would introduce oxidative damage to the DNA chain by changing the topological three forms [50,57-62]. Probably the size of the specific substituent at $\alpha$-position may determine the toxicity of the analyzed E. coli strains, including in particular R4, as evidenced by the obtained MIC and MBC values. The obtained results for individual compounds were statistically significant at the level of $p<0.05$. (Figure 6). 
3.4. Modification of Plasmid DNA Isolated from E. coli R2-R4 Strains with Tested $\alpha$-Hydroxy Phosphonate Derivatives

Performed studies proved that the analyzed and newly synthesized compounds can potentially be used as "substitutes" for the currently used antibiotics in hospital and clinical infections (Figures 7 and 8 and Supplementary Materials Figure S3).

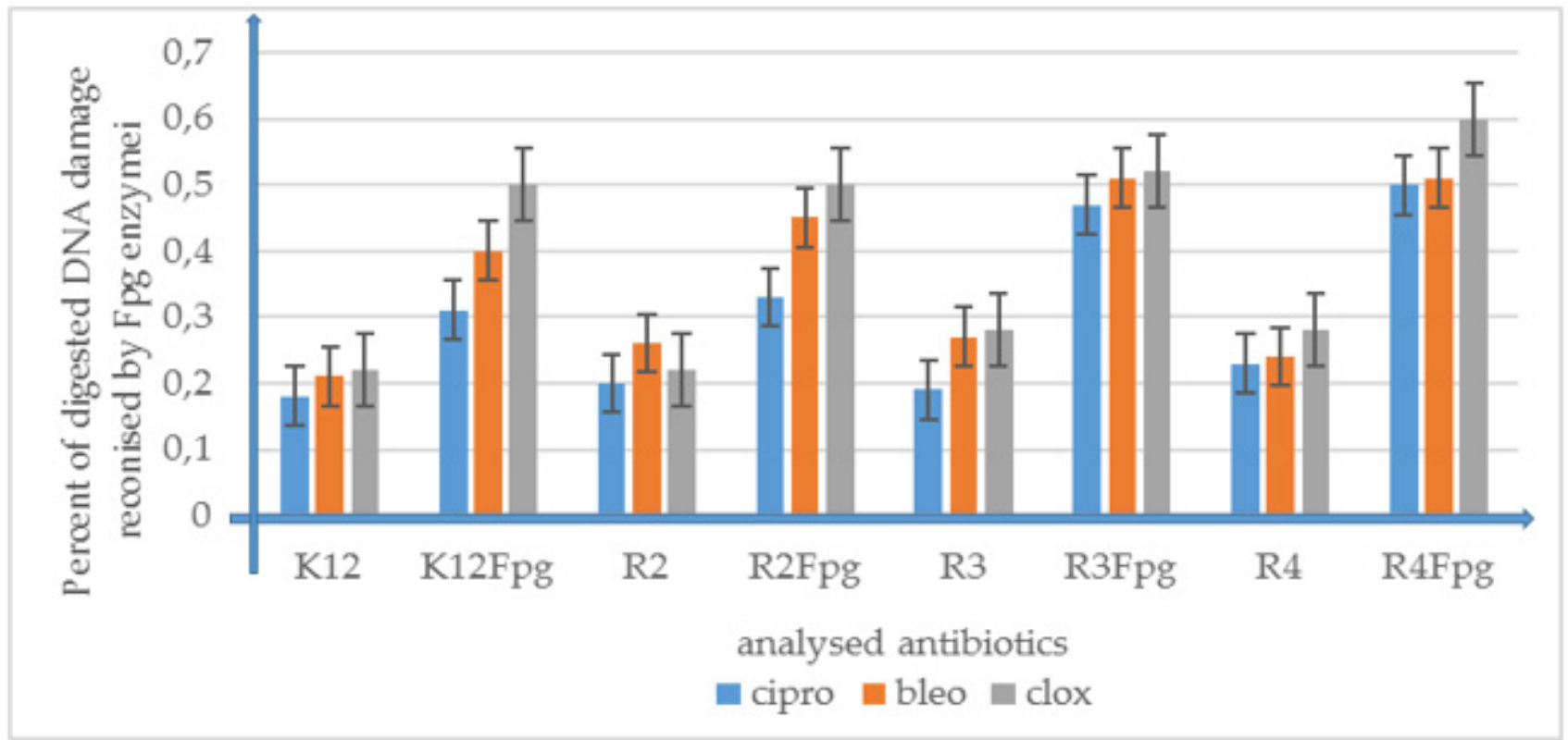

Figure 8. Percentage of bacterial DNA recognized by Fpg enzyme in model bacterial strains after ciprofloxacin, bleomycin, and cloxacillin treatment. The compounds were statistically significant at $p<0.05$. (See Supplementary Materials Figure S3).

Large modifications of plasmid DNA were observed for all analyzed compounds, especially for those marked with numbers 1-4 and $\mathbf{1 0}$ showed super selectivity in all analyzed bacterial strains, even differentiating the cytotoxicity in the K12 strain (See Supplementary Materials Figures S4-S24).

\section{Conclusions}

A novel enzymatic route towards target $\alpha$-acyloxy phosphonates which omits usage of toxic catalysts was develop. For the first time, a new and non-natural activity of lipases was shown in a Markovnikov addition reaction leading to the bioactive $\alpha$-acyloxy phosphonates in organic solvent. The protocol developed was used for the synthesis of series target products possessing methyl group at alpha position. This advanced activity of lipases is of fundamental importance in expanding the application of enzymes and in the evolution of new biocatalysts. Our discovered protocol offers facile metal-free synthesis, environmental sustainability, easy work-up procedure, and high yields of the target products (54-83\%). Toxic effect of the obtained phosphonate derivatives was evaluated on model E.coli strains. The analyzed phosphonate derivatives are able to modify all model strains of E. coli (R2-R4) and their bacterial DNA, changing the spatial structure of the LPS contained in their cell membranes. Among the derivatives studied, the compounds possessing methyl group at $\alpha$-position 5, 6, 7, 8, and 9 turned out to be the most active comparing to derivatives with aryl group at $\alpha$-position (Figure 2). The research results presented are important for understanding the biological properties of tested $\alpha$-hydroxy phosphonate derivatives as a function of potential new antibiotics and their toxic effects on Gram-negative bacteria in the face of the growing drug resistance pandemic, in reference to our previous works related to the characteristics of the model E.coli K12 and R2-R4 [44,51-65]. Finally, the analyzed $\alpha$-hydroxy phosphonate derivatives are more cytotoxic in the model bacterial cells than the commonly used antibiotics: ciprofloxacin, bleomycin, and cloxacillin. 
Supplementary Materials: The following supporting information can be downloaded at: https: / / www.mdpi.com/article/10.3390/ma15051975/s1. Figure S1: Examples of MIC and MBC on microplates with different concentration of studied compounds $\left(\mathrm{mg} \mathrm{L}^{-1}\right)$. Figure S2: An example of an agarose gel electrophoresis separation of isolated plasmids DNA from R4 strains modified with selected compounds. Figure S3: An example of an agarose gel electrophoresis separation of isolated plasmids DNA from R4 strains modified with antibiotics: cloxacilline, ciprofloxaclinie, and bleomycine digested (or not) with repair enzymes Fpg. Figure S4: 1H NMR (400 MHz, $\mathrm{CDCl} 3$ ) of dimethyl hydroxy-(2-nitrophenyl)methylphosphonate (2). Figure S5: 31P NMR (162 $\mathrm{MHz}, \mathrm{CDCl} 3$ ) of dimethyl hydroxy-(2-nitrophenyl)methylphosphonate (2). Figure S6: 1H NMR (400 MHz, CDCl3) of dibenzyl (1-hydroxy-2-phenylpropyl)phosphonate (4). Figure S7: 31P NMR (162 MHz, CDCl3) of dibenzyl (1-hydroxy-2-phenylpropyl)phosphonate (4). Figure S8: 1H NMR (400 MHz, CDCl3) of 1-(dimethoxyphosphoryl)ethyl cinnamate (5). Figure S9: ${ }^{31} \mathrm{P}$ NMR (162 $\mathrm{MHz}, \mathrm{CDCl}_{3}$ ) of 1-(dimethoxyphosphoryl)ethyl cinnamate (5). Figure S10: ${ }^{1} \mathrm{H}$ NMR $(400 \mathrm{MHz}$, $\left.\mathrm{CDCl}_{3}\right)$ of 1-benzoyloxy-1-diethylphosphonylethane (6). Figure S11: ${ }^{13} \mathrm{C} \mathrm{NMR}\left(100 \mathrm{MHz}, \mathrm{CDCl}_{3}\right)$ of 1-benzoyloxy-1-diethylphosphonylethane (6). Figure S12: ${ }^{31} \mathrm{P} \mathrm{NMR}\left(162 \mathrm{MHz}, \mathrm{CDCl}_{3}\right)$ of 1benzoyloxy-1-diethylphosphonylethane (6). Figure S13: ${ }^{1} \mathrm{H}$ NMR $\left(400 \mathrm{MHz}, \mathrm{CDCl}_{3}\right)$ of dibenzyl(1propionoxy ethyl)phosphonat (7).Figure S14: ${ }^{13} \mathrm{C} \mathrm{NMR}\left(100 \mathrm{MHz}, \mathrm{CDCl}_{3}\right)$ of dibenzyl(1-propionoxy ethyl)phosphonat (7). Figure S15: ${ }^{31} \mathrm{P} \mathrm{NMR}\left(162 \mathrm{MHz}, \mathrm{CDCl}_{3}\right)$ of dibenzyl(1-propionoxy ethyl)phosphonat (7). Figure S16: ${ }^{1} \mathrm{H}$ NMR (400 MHz, $\mathrm{CDCl}_{3}$ ) of 2,2-dimethylpropanyloxy1-dibenzylphosphonylethane (8). Figure S17: ${ }^{13} \mathrm{C}$ NMR $\left(100 \mathrm{MHz}, \mathrm{CDCl}_{3}\right.$ ) of 2,2-dimethylpropanyloxy1-dibenzylphosphonylethane (8). Figure S18: ${ }^{31} \mathrm{P} \mathrm{NMR}\left(162 \mathrm{MHz}, \mathrm{CDCl}_{3}\right)$ of 2,2-dimethylpropanyloxy1-dibenzylphosphonylethane (8). Figure S19: ${ }^{1} \mathrm{H}$ NMR $\left(400 \mathrm{MHz}, \mathrm{CDCl}_{3}\right.$ ) of 1-(dibenzylphosphoryl)ethyl dodecanoate (9). Figure S20: ${ }^{1} \mathrm{H}$ $\mathrm{NMR}\left(100 \mathrm{MHz}, \mathrm{CDCl}_{3}\right)$ of 1-(dibenzylphosphoryl)ethyl dodecanoate (9). Figure S21: ${ }^{31} \mathrm{P} \mathrm{NMR} \mathrm{(162} \mathrm{MHz,}$ $\mathrm{CDCl}_{3}$ ) of 1-(dibenzylphosphoryl)ethyl dodecanoate (9). Figure S22: ${ }^{1} \mathrm{H} \mathrm{NMR}\left(400 \mathrm{MHz}, \mathrm{CDCl}_{3}\right)$ of dimethyl 2-(dibenzyloxyphosphoryl)succinate (10). Figure S23: ${ }^{13} \mathrm{C} \mathrm{NMR}\left(100 \mathrm{MHz}, \mathrm{CDCl}_{3}\right)$ of dimethyl 2-(dibenzyloxyphosphoryl)succinate (10). Figure S24: ${ }^{31} \mathrm{P}$ NMR $\left(162 \mathrm{MHz}, \mathrm{CDCl}_{3}\right)$ of dimethyl 2-(dibenzyloxyphosphoryl)succinate (10).

Author Contributions: Conceptualization, P.K. and D.K.; methodology, P.K., D.K. and J.S.-G.; investigation, P.K.; resources, B.G. and P.K.; data curation, K.K., R.L. and A.W.; writing-original draft preparation, P.K., R.O. and D.K; writing-review and editing, D.K., R.O. and P.K.; supervision, P.K. All authors have read and agreed to the published version of the manuscript.

Funding: This work was supported by a grant from the Medical University of Białystok $\mathrm{SUB} / 2 / \mathrm{DN} / 22 / 001 / 2201$ and by the National Science Center, Poland, project OPUS No. 2019/33/B/ST4/01118.

Institutional Review Board Statement: Not applicable.

Informed Consent Statement: Not applicable.

Data Availability Statement: On request by those interested.

Acknowledgments: The authors thank Jolanta Łukasiewicz from the Ludwik Hirszfeld Institute of Immunology and Experimental Therapy (Polish Academy of Sciences) for providing the strains of E. coli.

Conflicts of Interest: The authors declare no conflict of interest.

\section{Abbreviations}

MIC minimum inhibitory concentration

MBC minimum bactericidal concentration

Oc open circle

Ccc covalently closed circle

BER base excision repair

Fpg DNA-formamidopyrimidine glycosylase 


\section{References}

1. Tulsi, N.S.; Downey, A.M.; Cairo, C.W. A protected l-bromophosphonomethylphenylalanine amino acid derivative (BrPmp) for synthesis of irreversible protein tyrosine phosphatase inhibitors. Bioorg. Med. Chem. 2010, 18, 8679-8686. [CrossRef] [PubMed]

2. Desai, J.; Wang, Y.; Wang, K.; Malwal, S.R.; Oldfield, E. Isoprenoid Biosynthesis Inhibitors Targeting Bacterial Cell Growth. ChemMedChem 2016, 11, 2205-2215. [CrossRef] [PubMed]

3. Jiang, G.; Madan, D.; Prestwich, G.D. Aromatic phosphonates inhibit the lysophospholipase D activity of autotaxin. Bioorg. Med. Chem. Lett. 2011, 21, 5098-5101. [CrossRef] [PubMed]

4. Rádai, Z.; Keglevich, G. Synthesis and Reactions of $\alpha$-Hydroxyphosphonates. Molecules 2018, 23, 1493. [CrossRef]

5. Abdou, W.M.; Bekheit, M.S. One-pot three-component synthesis of peptidomimics for investigation of antibacterial and antineoplastic properties. Arabian J. Chem. 2018, 11, 1260-1269. [CrossRef]

6. Shi, D.-Q.; Li, X.-J.; Wei, J. 5-Fluorouracil Derivatives Containing $\alpha$-Hydroxy Phosphonates. Phosphorus Sulfur Silicon Relat. Elem. 2007, 182, 405-415. [CrossRef]

7. Tian, C.; Xu, T.; Zhang, L.; Cheng, Z.; Zhu, X. RAFT copolymerization of a phosphorus-containing monomer with $\alpha$-hydroxy phosphonate and methyl methacrylate. RSC Adv. 2016, 6, 34659-34665. [CrossRef]

8. Vahdat, S.M.; Baharfar, R.; Tajbakhsh, M.; Heydari, A.; Baghbanian, S.M.; Khaksar, S. Organocatalytic synthesis of $\alpha$-hydroxy and $\alpha$-aminophosphonates. Tetrahedron Lett. 2008, 49, 6501-6504. [CrossRef]

9. Kiss, N.Z.; Rádai, Z.; Keglevich, G. Green syntheses of potentially bioactive $\alpha$-hydroxyphosphonates and related derivatives Phosphorus Sulfur Silicon Relat. Elem. 2019, 194, 1003-1006. [CrossRef]

10. Bálint, E.; Tajti, A.; Keglevich, G. Application of the Microwave Technique in Continuous Flow Processing of Organophosphorus Chemical Reactions. Materials 2019, 12, 788. [CrossRef]

11. Iwanejko, J.; Samadaei, M.; Pinter, M.; Senfter, D.; Madlener, S.; Kochel, A.; Rohr-Udilova, N.; Wojaczyńska, E. Cytotoxic Activity of Piperazin-2-One-Based Structures: Cyclic Imines, Lactams, Aminophosphonates, and Their Derivatives. Materials 2021, 14, 2138. [CrossRef] [PubMed]

12. Iwanejko, J.; Wojaczyńska, E.; Turlej, E.; Maciejewska, M.; Wietrzyk, J. Octahydroquinoxalin-2(1H)-One-Based Aminophosphonic Acids and Their Derivatives-Biological Activity towards Cancer Cells. Materials 2020, 13, 2393. [CrossRef] [PubMed]

13. Lewkowski, J.; Morawska, M.; Kaczmarek, A.; Rogacz, D.; Rychter, P. Novel N-Arylaminophosphonates Bearing a Pyrrole Moiety and Their Ecotoxicological Properties. Molecules 2017, 22, 1132. [CrossRef] [PubMed]

14. Gundluru, M.; Mallu, K.K.R.; Sarva, S.; Cirandur, S.R. Green and eco-friendly synthesis of $\alpha$-hydroxyphosphonates as antioxidant and antimicrobial agents. J. Mol. Struct. 2022, 1256, 132554. [CrossRef]

15. Brel', A.K.; Tyurenkov, I.N.; Strel'tsova, G.V.; Matyukhova, N.P.; Nazarenko, V.N.; Agarkova, N.S. Synthesis and biological activity of 2(3)-dialkylphosphonoalkyl acetates. Pharm. Chem. J. 1988, 22, 118-120. [CrossRef]

16. Koszelewski, D.; Ostaszewski, R. Biocatalytic Promiscuity of Lipases in Carbon-Phosphorus Bond Formation. Chem CatChem 2019, 11, 2554-2558. [CrossRef]

17. Hudson, H.R.; Yusuf, R.O.; Matthews, R.W. The Preparation of Dimethyl $\alpha$-Hydroxyphosphonates and the Chemical Shift Non-Equivalence of Their Diastereotopic Methyl Ester Groups. Phosphorus Sulfur Silicon Relat. Elem. 2008, 183, 1527-1540. [CrossRef]

18. Rádai, Z.; Windt, T.; Nagy, V.; Füredi, A.; Kiss, N.Z.; Ranđelović, I.; Tóvári, J.; Keglevich, G.; Szakács, G.; Tóth, S. Synthesis and anticancer cytotoxicity with structural context of an $\alpha$-hydroxyphosphonate based compound library derived from substituted benzaldehydes. New J. Chem. 2019, 43, 14028-14035. [CrossRef]

19. Wang, T.; Huang, H.J.; Luo, J.; Yu, D.H. Synthesis and Herbicidal Activity of O,O-Dimethyl-(3-Phenacryloyloxy) Alkyl Phosphonates. Phosphorus Sulfur Silicon Relat. Elem. 2012, 187, 135-141. [CrossRef]

20. Seto, H.; Kuzuyama, T. Bioactive natural products with carbon-phosphorus bonds and their biosynthesis. Nat. Prod. Rep. 1999, 16, 589-596. [CrossRef]

21. Rádai, Z.; Kiss, N.Z.; Keglevich, G. Synthesis of $\alpha$-Hydroxyphosphonates, an Important Class of Bioactive Compounds; György, K., Ed.; Organophosphorus Chemistry: Novel Developments; Walter de Gruyter: Berlin, Germany; Boston, MA, USA, 2018; pp. 91-107, 315p.

22. Chen, X.B.; Shi, D.Q. Synthesis and biological activity of novel phosphonate derivatives containing of pyridyl and 1,2,3-triazole rings. Phosphorus Sulfur Silicon Relat. Elem. 2008, 183, 1134-1144. [CrossRef]

23. Chen, T.; Shen, P.; Li, Y.; He, H. Synthesis and herbicidal activity of O,O-dialkyl phenoxyacetoxyalkylphosphonates containing fluorine. J. Fluorine Chem. 2006, 127, 291-295. [CrossRef]

24. Peng, H.; Wang, T.; Xie, P.; Chen, T.; He, H.W.; Wan, J. Molecular docking and three-dimensional quantitative structure-activity relationship studied on the binding modes of herbicidal 1-(substituted phenoxyacetoxy)alkylphosphonates to the E1 component of pyruvate dehydrogenase. J. Agric. Food Chem. 2007, 55, 1871-1880. [CrossRef] [PubMed]

25. Jiaqiang, Y.; Jun, M.; Wanli, C.; Minggang, L.; Gang, G.; Baoan, S. Microwave-Assisted Synthesis and Antitumor Activity of Salicyl Acyloxy Phosphonate Derivatives. Chin. J. Org. Chem. 2014, 34, 2566-2571. [CrossRef]

26. Wang, W.; Wang, L.P.; Ning, B.K.; Mao, M.Z.; Xue, C.; Wang, H.Y. Synthesis and insecticidal activities of O,O-dialkyl-2-[3-bromo1-(3-chloropyridin-2-yl)-1H-pyrazole-5-carbonyloxy] (aryl) methylphosphonates. Phosphorus Sulfur Silicon Relat. Elem. 2016, 191, 1362-1367. [CrossRef] 
27. Hudson, H.R.; Jászay, Z.M.; Pianka, M. The preparation and properties of some $\alpha$-acyloxy- and $\alpha$-carbamoyloxyphosphonothionates. Phosphorus Sulfur Silicon Relat. Elem. 2003, 178, 1571-1582. [CrossRef]

28. Long, Q.; Deng, X.; Gao, Y.; Xie, H.; Peng, H.; He, H. Synthesis and herbicidal activities of sodium hydrogen 1-(substituted phenoxyacetoxy)alkylphosphonates. Phosphorus Sulfur Silicon Relat. Elem. 2013, 188, 819-825. [CrossRef]

29. Firouzabadi, H.; Iranpoor, N.; Sobhani, S.; Amoozgar, Z. Copper triflate as a useful catalyst for the high-yielding preparation of $\alpha$-acetyloxyphosphonates under solvent-free conditions. Synthesis 2004, 2, 295-297. [CrossRef]

30. Firouzabadi, H.; Iranpoor, N.; Farahi, S. Solid trichlorotitanium(IV) trifluoromethanesulfonate $\mathrm{TiCl}_{3}(\mathrm{OTf})$ catalyzed efficient acylation of $-\mathrm{OH}$ and $-\mathrm{SH}$ : Direct esterification of alcohols with carboxylic acids and transesterification of alcohols with esters under neat conditions. J. Mol. Catal. A Chem. 2008, 289, 61-68. [CrossRef]

31. Green, D.; Elgendy, S.; Patel, G.; Skordalakes, E.; Goodwin, C.A.; Scully, M.F.; Kakkar, V.V.; Deadman, J.J. Substrate related O,O-dialkyldipeptidyly carboxybenzylphosphonates, a new type of thrombin inhibitor. Phosphorus Sulfur Silicon Relat. Elem. 2000, 156, 151-155. [CrossRef]

32. Rulev, A.Y. Recent advances in Michael addition of H-phosphonates. RSC Adv. 2014, 4, 26002-26012. [CrossRef]

33. Banerjee, I.; Panda, T.K. Recent advances in the carbon-phosphorus (C-P) bond formation from unsaturated compounds by sand p-block metals. Org. Biomol. Chem. 2021, 19, 6571-6587. [CrossRef] [PubMed]

34. Samarat, A.; Fargeas, V.; Villieras, J.; Lebreton, J.; Amri, H. A new synthesis of ( \pm )-homosarkomycin ethyl ester. Tetrahedron Lett. 2001, 42, 1273-1274. [CrossRef]

35. Jiang, Z.; Zhang, Y.; Ye, W.; Tan, C.-H. P-C Bond formation via direct and three-component conjugate addition catalyzed by 1, 5, 7-triazabicyclo [4.4.0] dec-5-ene (TBD). Tetrahedron Lett. 2007, 48, 51-54. [CrossRef]

36. Wozniak, L.A.; Bukowiecka-Matusiak, M.; Burzynska-Redziwatr, I.; Stec, W.J. Stereodefined dinucleoside $\left(3^{\prime}, 5^{\prime}\right)$-propionamidophosphonates and $\beta$-cyanoethylphosphonates and their incorporation into modified oligonucleotides. Tetrahedron Lett. 2009, 50, 2620-2623. [CrossRef]

37. Liu, S.; Shao, N.; Li, F.-Z.; Yang, X.-C.; Wang, M.C. Azetidine-derived dinuclear zinc catalyzed asymmetric phospha-Michael addition of dialkyl phosphite to $\alpha, \beta$-unsaturated carbonyl compounds. Org. Biomol. Chem. 2017, 15, 9465-9474. [CrossRef]

38. McConnell, R.L.; Coover, H.W., Jr. Preparation and Properties of Diethyl Acetoxyalkylphosphonates. J. Am. Chem. Soc. 1957, 79, 1961-1963. [CrossRef]

39. Mąosza, M.; Wojciechowski, K. Synthesis of Phosphonic Acid Esters in Solid-Liquid Catalytic Two-Phase System. Bull. Pol. Acad. Sci. Chem. 1984, 32, 175-179.

40. Priego, J.; Ortiz-Nava, C.; Carrillo-Morales, M.; Lopez-Mungura, A.; Escalante, J.; Castillo, E. Solvent engineering: An effective tool to direct chemoselectivity in a lipase-catalyzed Michael addition. Tetrahedron 2009, 65, 536-539. [CrossRef]

41. Cai, Y.; Wu, Q.; Xiao, Y.-M.; Lv, D.-S.; Lin, X.-F. Hydrolase-catalyzed Michael addition of imidazoles to acrylic monomers in organic medium. J. Biotechnol. 2006, 121, 330-337. [CrossRef]

42. Torre, O.; Alfonso, I.; Gotor, V. Lipase catalysed Michael addition of secondary amines to acrylonitrile. Chem. Commun. 2004, 435, 1724-1725. [CrossRef] [PubMed]

43. Carlqvist, P.; Svedendahl, M.; Branneby, C.; Hult, K.; Brinck, T.; Berglund, P. Exploring the active-site of a rationally redesigned lipase for catalysis of Michael-type additions. ChemBioChem 2005, 6, 331-336. [CrossRef] [PubMed]

44. Guezane-Lakoud, S.; Toffano, M.; Aribi-Zouioueche, L. Promiscuous lipase catalyzed a new P-C bond formation: Green and efficient protocol for one-pot synthesis of $\alpha$-aminophosphonates. Heteroatom Chem. 2017, 28, e21408. [CrossRef]

45. Lou, F.-W.; Liu, B.; Wu, Q.; Lv, D.-S.; Lin, X.-F. Candida antarctica Lipase B (CAL-B)-Catalyzed Carbon-Sulfur Bond Addition and Controllable Selectivity in Organic Media. Adv. Synth. Catal. 2008, 350, 1959-1962. [CrossRef]

46. Liu, B.-K.; Wu, Q.; Lv, D.S.; Chen, X.-Z.; Lin, X.-F. New view of acylase promiscuity: An extended study on the acylase-catalyzed Markovnikov addition. J. Mol. Catal. B Enzym. 2011, 73, 85-89. [CrossRef]

47. Lou, F.-W.; Liu, B.K.; Wu, Q.; Lv, D.-S.; Lin, X.-F. Controllable enzymatic Markovnikov addition and acylation of thiols to vinyl esters. J. Mol. Catal. B Enzym. 2009, 60, 64-68. [CrossRef]

48. Wu, W.-B.; Xu, J.-M.; Wu, Q.; Lv, D.S.; Lin, X.-F. Promiscuous Acylases-Catalyzed Markovnikov Addition of N-Heterocycles to Vinyl Esters in Organic Media. Adv. Synth. Catal. 2006, 348, 487-492. [CrossRef]

49. Dwivedee, B.P.; Soni, S.; Sharma, M.; Bhaumik, J.; Laha, J.K.; Banerjee, U.C. Promiscuity of Lipase-Catalyzed Reactions for Organic Synthesis: A Recent Update. ChemstrySelect 2018, 3, 2441-2466. [CrossRef]

50. Koszelewski, D.; Ostaszewski, R.; Śmigielski, P.; Hrunyk, A.; Kramkowski, K.; Laskowski, Ł.; Laskowska, M.; Lizut, R.; Szymczak, M.; Michalski, J.; et al. Pyridine Derivatives-A New Class of Compounds That Are Toxic to E. coli K12, R2-R4 Strains. Materials 2021, 14, 5401. [CrossRef]

51. Trzepizur, D.; Brodzka, A.; Koszelewski, D.; Ostaszewski, R. Selective Esterification of Phosphonic Acids. Molecules $2021,26,5637$. [CrossRef]

52. Koszelewski, D.; Paprocki, D.; Brodzka, A.; Kęciek, A.; Wilk, M.; Ostaszewski, R. The sustainable copper-catalyzed direct formation of highly functionalized p-quinols in water. Sustain. Chem. Pharm. 2022, 25, 100576. [CrossRef]

53. Trzepizur, D.; Brodzka, A.; Koszelewski, D.; Wilk, M.; Ostaszewski, R. Selective Palladium-Catalyzed $\alpha$, $\beta$-Homodiarylation of Vinyl Esters in Aqueous Medium. Eur. J. Org. Chem. 2021, 2021, 6028-6036. [CrossRef]

54. Zhang, J.; Wang, C.; Wang, C.; Shang, W.; Xiao, B.; Duan, S.; Li, F.; Wang, L.; Chen, P. Lipase-catalyzed aza-Michael addition of amines to acrylates in supercritical carbon dioxide. J. Chem. Technol. Biotechnol. 2019, 94, 3981-3986. [CrossRef] 
55. Albanese, D.C.M.; Gaggero, N. Albumin as a promiscuous biocatalyst in organic synthesis. RSC Adv. 2015, 5, 10588-10598. [CrossRef]

56. Zaks, A.; Klibanov, A.M. Enzymatic catalysis in organic media at $100{ }^{\circ}$ C. Science 1984, 224, 1249-1251. [CrossRef]

57. Kowalczyk, P.; Trzepizur, D.; Szymczak, M.; Skiba, G.; Kramkowski, K.; Ostaszewski, R. 1,2-Diarylethanols-A New Class of Compounds That Are Toxic to E. coli K12, R2-R4 Strains. Materials 2021, 14, 1025. [CrossRef]

58. Kowalczyk, P.; Madej, A.; Szymczak, M.; Ostaszewski, R. $\alpha$-Amidoamids as New Replacements of Antibiotics-Research on the Chosen K12, R2-R4 E. coli Strains. Materials 2020, 13, 5169. [CrossRef]

59. Kowalczyk, P.; Borkowski, A.; Czerwonka, G.; Cłapa, T.; Cieśla, J.; Misiewicz, A.; Borowiec, M.; Szala, M. The microbial toxicity of quaternary ammonium ionic liquids is dependent on the type of lipopolysaccharide. J. Mol. Liq. 2018, 266, 540-547. [CrossRef]

60. Borkowski, A.; Kowalczyk, P.; Czerwonka, G.; Cieśla, J.; Cłapa, T.; Misiewicz, A.; Szala, M.; Drabik, M. Interaction of quaternary ammonium ionic liquids with bacterial membranes-Studies with Escherichia coli R1-R4-type lipopolysaccharides. J. Mol. Liq. 2017, 246, 282-289. [CrossRef]

61. Kowalczyk, P.; Gawdzik, B.; Trzepizur, D.; Szymczak, M.; Skiba, G.; Raj, S.; Kramkowski, K.; Lizut, R.; Ostaszewski, R. $\delta$-Lactones-A New Class of Compounds That Are Toxic to E. coli K12 and R2-R4 Strains. Materials 2021, 14, 2956. [CrossRef]

62. Kowalczyk, P.; Wilk, M.; Parul, P.; Szymczak, M.; Kramkowski, K.; Raj, S.; Skiba, G.; Sulejczak, D.; Kleczkowska, D.; Ostaszewski, R. The Synthesis and Evaluation of Aminocoumarin Peptidomimetics as Cytotoxic Agents on Model Bacterial E. coli Strains. Materials 2021, 14, 5725. [CrossRef] [PubMed]

63. Dissanayake, D.R.; Wijewardana, T.G.; Gunawardena, G.A.; Poxton, I.R. Distribution of lipopolysaccharide core types among avian pathogenic Escherichia coli in relation to the major phylogenetic groups. Vet. Microbiol. 2008, 132, 355-363. [CrossRef] [PubMed]

64. Maciejewska, A.; Kaszowska, M.; Jachymek, W.; Lugowski, C.; Lukasiewicz, J. Lipopolysaccharide-linked Enterobacterial Common Antigen (ECALPS) Occurs in Rough Strains of Escherichia coli R1, R2, and R4. Int. J. Mol. Sci. 2020, 21, 6038. [CrossRef] [PubMed]

65. Prost, M.E.; Prost, R. Basic parameters of evaluation of the effectiveness of antibiotic therapy. OphthaTherapy 2017, 4, 233-236. [CrossRef] 